\title{
ANALISIS KESALAHAN MAHASISWA MATEMATIKA DALAM MENYELESAIKAN SOAL- SOAL LOGIKA
}

\author{
Yulia Romadiastri \\ Dosen Tadris Matematika Fakultas Tarbiyah IAIN Walisongo \\ Semarang
}

\begin{abstract}
ABSTRAK
Logika adalah salah satu materi dasar untuk mahasiswa matematika yang bersifat abstrak, sehingga tidak sedikit mahasiswa yang mengalami kesulitan dalam mempelajarinya. Banyaknya kesalahan yang dilakukan mahasiswa dalam mengerjakan soal bisa menjadi petunjuk sejauh mana tingkat penguasaan materi mereka. Tujuan penelitian ini adalah untuk mengetahui letak kesalahan mahasiswa dan mengetahui faktor-faktor yang menyebabkan kesalahan mahasiswa dalam menyelesaikan soal-soal logika. Metode pengumpulan data yang digunakan adalah metode dokumentasi, metode tes, dan metode wawancara. Penelitian ini menggunakan metode deskriptif dan bersifat kualitatif. Subjek penelitian adalah mahasiswa Prodi Tadris Matematika Semester 1 Fakultas Tarbiyah IAIN Walisongo Semarang yang diambil satu kelas yaitu kelas TM1A. Hasil yang diperoleh adalah bahwa kesalahan mahasiswa terbagi menjadi tiga kategori yaitu pada
\end{abstract}


kesalahan pemahaman konsep-konsep logika, kesalahan dalam keterampilan menyelesaikan soal dan kesalahan dalam pemecahan masalah. Yang melakukan kesalahan pada pemahaman konsep sebesar 7,5\%, kesalahan pada keterampilan menyelesaikan soal sebesar 22,1\% dan kesalahan dalam memecahkan masalah sebesar 17,3\%. Adapun faktor-faktor yang menyebabkan mahasiswa mengalami kesalahan dalam menyelesaikan soal logika adalah: mahasiswa tidak menguasai konsep-konsep pada materi sebelumnya yang menjadi materi prasyarat, materi yang bersifat abstrak sehingga mahasiswa merasa bosan, dan kurangnya berlatih dalam mengerjakan soal-soal logika.

Kata kunci: analisis kesalahan, matematika, logika.

\section{PENDAHULUAN}

Pada kurikulum mata kuliah dasar yang ada di Program Studi Tadris Matematika Fakultas Tarbiyah IAIN Walisongo Semarang, terdapat beberapa materi atau mata kuliah yang bersifat abstrak, sehingga tidak sedikit mahasiswa yang merasa kesulitan dalam mempelajarinya. Karena memang salah satu ciri dari ilmu matematika adalah bersifat abstrak. Tentu saja hal ini membuat banyak orang yang mempelajari matematika terutama mahasiswa matematika sendiri mengalami kesulitan. Dibutuhkan ketelitian, keterampilan dan kecepatan dalam berfikir saat mempelajari materi-materi tersebut, tidak terkecuali dalam mata kuliah Pengantar Dasar Matematika (PDM) yang diantaranya berisi materi logika.

Mata kuliah ini memiliki karakteristik yang cukup abstrak, dan di dalamnya berisi cukup banyak teorema yang harus dikuasai dan dipahami, walaupun masih berupa konsep-konsep dasar yang sederhana. Akibatnya, banyak mahasiswa yang menganggap mata kuliah tersebut cukup sulit, padahal mata kuliah PDM adalah mata kuliah dasar yang wajib diambil dan dikuasai oleh semua mahasiswa Tadris Matematika dan merupakan mata 
kuliah prasyarat untuk mata kuliah keahlian berikutnya. Karena materi-materi dalam mata kuliah PDM merupakan materi dasar dan materi ini harus dikuasai oleh mahasiswa sebab materi ini termasuk dalam kurikulum matematika di tingkat SMA/MA. Sehingga lulusan Prodi Tadris Matematika yang dididik untuk menjadi guru baik di tingkat SD/MI, SMP/MTs, maupun SMA/ MA sudah mempunyai bekal yang cukup untuk diterjunkan di masyarakat.

Ilmu matematika bersifat hierarki, yang artinya berjenjang. Artinya, konsep pada materi sebelumnya akan digunakan dan diterapkan pada materi berikutnya. Sehingga jika pada konsepkonsep dasar sebelumnya mahasiswa belum menguasai dengan baik, maka mereka akan mengalami kesulitan pada materi berikutnya. Sementara tingkatan materi juga semakin abstrak, akibatnya dengan dasar/pondasi yang tidak kuat akan membuat mahasiswa semakin bingung. Imbas yang terasa kuat ada pada mahasiswa semester tinggi yang akan menempuh praktik mengajar di sekolah-sekolah dan juga mahasiswa yang akan menempuh ujian komprehensif ataupun ujian skripsi.

Mata kuliah PDM diberikan pada semester 1, sehingga pesertanya adalah mahasiswa-mahasiswa baru yang masih terbiasa dengan pola pembelajaran di tingkat SMU/MA. Sebagian besar mahasiswa baru ini masih menggunakan cara belajar dengan mengutamakan hafalan yang dapat menyebabkan kesalahpahaman dalam mengembangkan konsep dasar yang dikuasainya untuk menyelesaikan berbagai macam pengembangan soal. Selain itu mereka juga cenderung pasif karena belum mengenal dunia perkuliahan dan masih merasa takut terutama untuk bertanya terhadap dosen yang mengampu mata kuliah. Apalagi mereka hanya mengandalkan menerima materi dari ruang perkuliahan saja tanpa ada inisiatif mencari sendiri di luar jam perkuliahan melalui fasilitas-fasilitas yang telah disediakan. Hal ini menambah permasalahan tersendiri baik bagi dosen maupun bagi mahasiswa itu sendiri.

Banyaknya kesalahan yang dilakukan mahasiswa dalam mengerjakan soal bisa menjadi petunjuk sejauh mana pengua- 
saan mereka terhadap materi-materi yang ada. Dari kesalahan yang dilakukan, dapat diteliti dan dikaji lebih lanjut mengenai sumber kesalahan mahasiswa. Sumber kesalahan yang dilakukan mahasiswa harus segera mendapat pemecahan yang tuntas. Pemecahan ini ditempuh dengan cara menganalisis akar permasalahan yang menjadi penyebab kesalahan yang dilakukan oleh mahasiswa. Selanjutnya diupayakan alternatif pemecahannya, sehingga kesalahan yang sama tidak akan terulang lagi dikemudian hari. Penelitian ini akan menggali di mana letak kesalahan mahasiswa khususnya di Program Studi Tadris Matematika Fakultas Tarbiyah IAIN Walisongo Semarang dan mengidentifikasi faktor-faktor apa saja yang meyebabkan mahasiswa matematika mengalami kesalahan dalam menyelesaikan soal-soal logika.

\section{PEMBELAJARAN MATEMATIKA}

Matematika merupakan salah satu bagian yang penting dalam bidang ilmu pengetahuan. Apabila dilihat dari sudut pengklasifikasian bidang ilmu pengetahuan, pelajaran matematika termasuk ke dalam kelompok ilmu-ilmu eksakta, yang lebih banyak memerlukan pemahaman dari pada hafalan. Untuk dapat memahami suatu pokok bahasan dalam matematika, peserta didik harus mampu menguasai konsep-konsep matematika dan keterkaitannya serta mampu menerapkan konsep-konsep tersebut untuk memecahkan masalah yang dihadapinya.

Matematika merupakan bidang studi yang dipelajari oleh semua jenjang pendidikan dasar, menengah, bahkan beberapa perguruan tinggi. Ada beberapa alasan tentang perlunya matematika diajarkan kepada peserta didik, yaitu karena:

1. Matematika selalu digunakan dalam segala segi kehidupan

2. Semua bidang studi memerlukan keterampilan matematika yang sesuai

3. Merupakan saran komunikasi yang kuat, singkat, dan jelas

4. Dapat digunakan untuk menyajikan informasi dalam berbagai cara

5. Meningkatkan kemampuan berpikir logis, ketelitian, dan 
kesadaran keruangan

6. Memberikan kepuasan terhadap usaha memecahkan masalah yang menantang. ${ }^{1}$

Lerner (dalam Mulyono Abdurrahman, 1999) mengemukakan bahwa kurikulum bidang studi matematika hendaknya mencakup tiga elemen, yaitu:

1) Konsep

Konsep menunjuk pada pemahaman dasar. Peserta didik mengembangkan suatu konsep ketika mereka mampu mengklasifikasikan atau mengelompokkan benda-benda atau ketika mereka dapat mengasosiasikan suatu nama dengan kelompok benda tertentu;

2) Keterampilan

Keterampilan menunjuk pada sesuatu yang dilakukan oleh seseorang, sebagai contoh, proses dalam menggunakan operasi dasar dalam penjumlahan, pengurangan, perkalian, dan pembagian adalah suatu jenis keterampilan matematika. Suatu keterampilan dapat dilihat dari kinerja anak secara baik atau kurang baik, secara cepat atau lambat, dan secara mudah atau sangat sukar. Keterampilan cenderung berkembang dan dapat ditingkatkan melalui latihan;

3) Pemecahan masalah

Pemecahan masalah adalah aplikasi dari konsep dan keterampilan. Dalam pemecahan masalah biasanya melibatkan beberapa kombinasi konsep dan keterampilan dalam suatu situasi baru atau situasi yang berbeda dari sebelumnya. Sebagai contoh, pada saat peserta didik diminta untuk mengukur luas layang-layang pada panjang garis singgung lingkaran, beberapa konsep dan keterampilan ikut terlibat. Beberapa konsep yang terlibat adalah layang-layang, garis sejajar, dan sisi, dan beberapa

${ }^{1}$ Windarti, Sri, “Dunia Matematika”, dalam http://sriwindarti. wordpress.com/2009/03/17/mengembangkan-evaluasi-alternatif/, diakses 3 Mei 2011. 
keterampilan yang terlibat adalah keterampilan mengukur, menjumlahkan dan mengalikan; ${ }^{2}$

Tiga elemen tersebut yang akan dikaji untuk mengetahui dimana letak kesalahan mahasiswa dalam menyelesaikan soalsoal logika.

\section{ANALISIS KESALAHAN}

Dalam belajar matematika diperlukan kemampuan belajar abstrak, seperti dikemukakan oleh R. Soedjadi dan Masriyah dalam Amin Suyitno ${ }^{3}$. Belajar abstrak adalah belajar dengan menggunakan cara-cara berpikir abstrak. Tujuannya adalah untuk memperoleh pemahaman dan pemecahan masalah-masalah abstrak yang ada dalam matematika. Dalam belajar matematika seringkali peserta didik melakukan kesalahan-kesalahan khususnya dalam menyelesaikan soalsoal matematika.

Dalam proses belajar mengajar guru sangat diperlukan untuk mengatasi kesalahan peserta didik. Namun guru tidak dapat mengambil keputusan dalam membantu peserta didiknya yang mengalami kesulitan belajar jika guru tidak tahu di mana letak kesulitannya. Oleh karena itu seorang guru perlu mengetahui kesulitan peserta didik dalam belajar matematika dan juga mengetahui penyebabnya. Sebagaimana di jelaskan dalam Q.S. Yusuf Ayat 68:

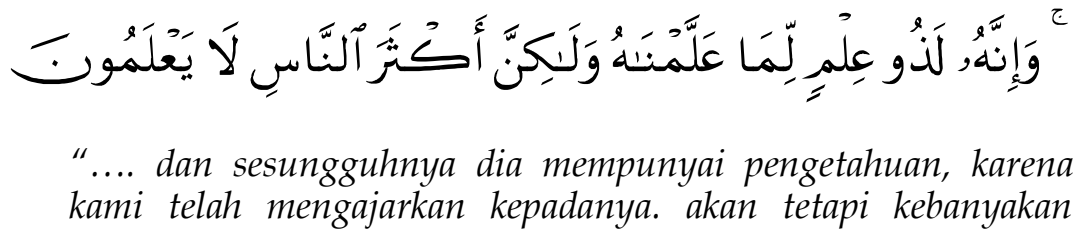

${ }^{2}$ Abdurrahman, Mulyono, 1999. Pendidikan Bagi Anak Berkesulitan Belajar, Jakarta: Rineka Cipta. hlm. 253-254.

3 Suyitno, Amin, 2004. Dasar-dasar dan Proses Pembelajaran Matematika I. Semarang: Unnes. 
manusia tiada mengetahui". (Q.S. Yusuf/12:68)4

Ayat di atas menerangkan bahwa manusia dalam menghadapi setiap urusan harus menggunakan jalan atau cara yang tepat tentunya dengan persiapan dan suatu uasaha untuk mencapai suatu tujuan. ${ }^{5}$

Menurut Subanji dan Mulyoto dalam Azis Asrofi, jenis-jenis kesalahan yang dilakukan siswa dalam menyelesaikan soal-soal matematika antara lain:

1. Kesalahan konsep

Indikatornya adalah:

a. Kesalahan menentukan teorema atau rumus untuk menjawab suatu masalah.

b. Penggunaan teorema atau rumus oleh siswa tidak sesuai dengan kondisi prasyarat berlakunya rumus tersebut atau tidak menuliskan teorema.

2. Kesalahan menggunakan data

Indikatornya adalah:

a. Tidak menggunakan data yang seharusnya dipakai.

b. Kesalahan memasukkan data ke variabel.

c. Menambah data yang tidak diperlukan dalam menjawab suatu masalah.

3. Kesalahan interpretasi bahasa

Indikatornya adalah:

a. Kesalahan dalam menyatakan bahasa sehari-hari dalam bahasa matematika.

b. Kesalahan menginterpretasikan simbol-simbol, grafik, dan tabel ke dalam bahasa matematika.

4. Kesalahan teknis

Indikatornya meliputi:

a. Kesalahan perhitungan atau komputasi.

${ }^{4}$ Muhammad Yunus, Terjemah al-Qur'an al-Karim, (Bandung:PT alMa'arif, 1994), hlm. 244

5 Ahmad Musthofa Al-Maraghi, Terjemah Tafsir Al-Maraghi 13, (Seamarang : PT. Karya Toha Putra Semarang, 1993), hlm. 29 
b. Kesalahan memanipulasi operasi aljabar.

5. Kesalahan penarikan kesimpulan

Indikatornya adalah:

a. Melakukan penyimpulan tanpa alasan pendukung yang benar.

b. Melakukan penyimpulan pernyataan yang tidak sesuai dengan penalaran logis.

Menurut Murwati, kesalahan-kesalahan yang dilakukan siswa dalam mengerjakan soal-soal matematika dapat diidentifikasi menjadi beberapa aspek, antara lain:

\section{Aspek bahasa}

Aspek bahasa merupakan kesulitan dan kekeliruan siswa dalam menafsirkan kata-kata atau simbol-simbol dan bahasa yang digunakan dalam matematika.

\section{Aspek imaginasi}

Aspek imaginasi merupakan kesulitan dan kekeliruan siswa dalam imajinasi ruang (spasial) dalam dimensi-dimensi tiga yang berakibat salah dalam mengerjakan soal-soal matematika.

\section{Aspek prasyarat}

Aspek prasyarat merupakan kesalahan dan kekeliruan siswa dalam mengerjakan soal matematika karena bahan pelajaran yang sedang dipelajari siswa belum dikuasai.

\section{Aspek tanggapan}

Aspek tanggapan merupakan kekeliruan dalam penafsiran atau tanggapan siswa terhadap konsepsi, rumus-rumus, dan dalil-dalil matematika dalam mengerjakan soal matematika.

\section{Aspek terapan}

Aspek terapan merupakan kekeliruan siswa dalam menerapkan rumus-rumus dan dalil-dalil matematika dalam menger- 
jakan soal matematika.

Fokus permasalahan dalam penelitian ini adalah kesalahan apa saja yang dialami mahasiswa dalam menyelesaikan soal-soal logika dan faktor-faktor apa saja yang menjadi penyebabnya. Sedangkan ruang lingkup dalam penelitian ini adalah mata kuliah PDM, dan objek atau variabel penelitian yang akan dianalisis adalah mengenai kesalahan mahasiswa dalam penguasaan:

1. Konsep

Indikatornya adalah:

a. Kesulitan dalam menentukan rumus untuk menyelesaikan suatu masalah.

b. Mahasiswa dalam menggunakan teorema atau rumus tidak sesuai dengan kondisi prasyarat berlakunya rumus tersebut atau tidak menuliskan teorema.

2. Keterampilan

Indikatornya adalah: mahasiswa kesulitan dalam menerapkan rumus yang berupa argumen-argumen kecil yang ada dalam menarik kesimpulan.

\section{Pemecahan masalah}

Indikatornya adalah: mahasiswa tidak dapat melanjutkan pekerjaannya dalam menyelesaikan soal.

\section{PEMBAHASAN}

Dari masing-masing butir soal yang diujikan pada kelas penelitian, diidentifikasi kesalahan-kesalahan yang dilakukan oleh mahasiswa berdasarkan jenis kesalahan sesuai dengan indikator-indikator yang telah ditentukan. Berikut tabel jenis kesalahan yang dialami mahasiswa dalam menyelesaikan soal-soal logika. 
Tabel 1

Jenis kesalahan yang dialami mahasiswa dalam menyelesaikan soal-soal logika

\begin{tabular}{|c|c|c|c|c|c|c|c|}
\hline \multirow{2}{*}{ Jenis } & \multicolumn{5}{|c|}{ Butir Soal } & Jml & $\begin{array}{c}\text { Prosen- } \\
\text { tase Ke- } \\
\text { salahan }\end{array}$ \\
\hline & \multicolumn{7}{|c|}{} \\
\cline { 2 - 8 } & 1 & 2 & 3 & 4 & 5 & & \\
\hline Konsep & 1 & 1 & 4 & 4 & 4 & 14 & $7,5 \%$ \\
\hline $\begin{array}{c}\text { Keterampi- } \\
\text { lan }\end{array}$ & 7 & 5 & 10 & 12 & 7 & 41 & $22,1 \%$ \\
\hline $\begin{array}{c}\text { Pemecahan } \\
\text { Masalah }\end{array}$ & 14 & 1 & 4 & 10 & 3 & 32 & $17,3 \%$ \\
\hline Jumlah & 22 & 7 & 18 & 26 & 14 & & \\
\hline $\begin{array}{c}\text { Prosen- } \\
\text { tase }\end{array}$ & $59,5 \%$ & $18,9 \%$ & $48,6 \%$ & $70,3 \%$ & $37,8 \%$ & & \\
\hline
\end{tabular}

Dari hasil di atas dapat diketahui bahwa mahasiswa yang mengalami kesalahan pada konsep sebesar 7,5\%, kesalahan pada keterampilan sebesar 22,1\% dan kesalahan pada pemecahan masalah sebesar 17,3\%. Jadi dapat disimpulkan kesalahan tertinggi mahasiswa dalam menyelesaikan soal-soal logika terletak pada keterampilan yaitu sebesar 22,1\%. Selanjutnya diperoleh data sebagai berikut.

\section{Soal nomor 1}

Berdasarkan analisis yang telah dilakukan terhadap seluruh jawaban mahasiswa diperoleh hasil bahwa ada 59,5\% atau 22 mahasiswa yang melakukan kesalahan pada soal nomor 1, dengan rincian sejumlah 1 mahasiswa dari kelompok bawah masih mengalami kesalahan dalam memahami konsep logika. Sedangkan 2 mahasiswa dari kelompok atas, 2 mahasiswa dari kelompok sedang, dan 3 mahasiswa dari kelompok bawah men- 
galami kesalahan pada keterampilan. Dan ada 8 mahasiswa dari kelompok atas, 5 mahasiswa dari kelompok sedang, serta 1 mahasiswa dari kelompok bawah mengalami kesalahan pada pemecahan masalah.

\section{Soal nomor 2}

Berdasarkan analisis yang telah dilakukan terhadap seluruh jawaban mahasiswa diperoleh hasil bahwa ada 18,9\% atau 7 mahasiswa yang melakukan kesalahan pada soal nomor 2, dengan rincian ada 1 mahasiswa dari kelompok bawah mengalami kesalahan pada bagian konsep. Kemudian 2 mahasiswa dari kelompok atas, 1 mahasiswa dari kelompok sedang, dan 2 mahasiswa dari kelompok bawah mengalami kesalahan dalam keterampilan. Berikutnya ada 1 mahasiswa dari kelompok bawah yang mengalami kesalahan pada pemecahan masalah.

\section{Soal nomor 3}

Berdasarkan analisis yang telah dilakukan terhadap seluruh jawaban mahasiswa diperoleh hasil bahwa ada 48,6\% atau 18 mahasiswa yang melakukan kesalahan pada soal nomor 3, dengan rincian sejumlah 2 mahasiswa dari kelompok atas , 1 mahasiswa dari kelompok sedang, dan 1 mahasiswa dari kelompok bawah mengalami kesalahan pada bagian konsep. Selanjutnya 3 mahasiswa dari kelompok atas, 3 mahasiswa dari kelompok sedang, dan 4 mahasiswa dari kelompok bawah mengalami kesalahan pada keterampilan. Serta 2 mahasiswa dari kelompok atas dan 2 mahasiswa dari kelompok sedang tidak dapat menyelesaikan soal tersebut.

\section{Soal nomor 4}

Berdasarkan analisis yang telah dilakukan terhadap seluruh jawaban mahasiswa diperoleh hasil bahwa ada 70,3\% atau 26 mahasiswa yang melakukan kesalahan pada soal nomor 4 , dengan rincian sejumlah 1 mahasiswa dari kelompok atas, 2 mahasiswa dari kelompok sedang, dan 1 mahasiswa dari kelompok bawah mengalami kesalahan pada bagian konsep. Dan 5 maha- 
siswa dari kelompok atas, 3 mahasiswa dari kelompok sedang, serta 4 mahasiswa dari kelompok bawah mengalami kesalahan pada bagian keterampilan. Berikutnya 7 mahasiswa dari kelompok atas dan 3 mahasiswa dari kelompok sedang tidak dapat menyelesaikan soal tersebut.

\section{Soal nomor 5}

Berdasarkan analisis yang telah dilakukan terhadap seluruh jawaban mahasiswa diperoleh hasil bahwa ada 37,8\% atau 14 mahasiswa yang melakukan kesalahan pada soal nomor 5, dengan rincian sejumlah 1 mahasiswa dari kelompok atas, 1 mahasiswa dari kelompok sedang, dan 2 mahasiswa dari kelompok bawah mengalami kesalahan dalam pemahaman konsep. Kemudian ada 2 mahasiswa dari kelompok atas, 2 mahasiswa dari kelompok sedang, dan 3 mahasiswa dari kelompok bawah mengalami kesalahan dalam keterampilan. Berikutnya ada 1 mahasiswa dari kelompok atas dan 2 mahasiswa dari kelompok sedang mengalami kesalahan pada pemecahan masalah

Dalam penelitian ini, selanjutnya diambil 6 subjek penelitian yang akan diteliti lebih lanjut untuk mengetahui faktor apa yang menyebabkan mahasiswa mengalami kesalahan dalam menyelesaikan soal-soal logika, yaitu dari kelompok atas: Nadhiroh dan Sulis Istianah, dari kelompok sedang: Ahmad Syafi'i dan Tajkiyah, serta dari kelompok bawah: Lutfiyah Nur Zain dan Ibnu Wahid. Berikut hasil data yang diperoleh mengenai kesalahan yang dialami mahasiswa (subjek penelitian).

Tabel 2

Data Jenis Kesalahan Mahasiswa Subjek Penelitian

\begin{tabular}{|c|l|c|c|c|c|c|}
\hline \multirow{2}{*}{ Kelompok } & \multirow{2}{*}{ Subjek Penelitian } & \multicolumn{5}{|c|}{ Butir Soal } \\
\cline { 3 - 7 } & & $\mathbf{1}$ & $\mathbf{2}$ & $\mathbf{3}$ & $\mathbf{4}$ & $\mathbf{5}$ \\
\hline \multirow{3}{*}{ Atas } & Nadhiroh & & & I & II & \\
\cline { 2 - 7 } & Sulia Istianah & & & II & & I \\
\hline
\end{tabular}




\begin{tabular}{|c|l|c|c|c|c|c|}
\hline \multirow{3}{*}{ Sedang } & Ahmad Syafi'i & II & & I & II & III \\
\cline { 2 - 7 } & Tajkiyah & III & & II & I & II \\
\hline \multirow{3}{*}{ Bawah } & Lutfiyah Nur Z.ain & I & I & II & II & I \\
\cline { 2 - 7 } & Ibnu Wahid & II & III & II & II & II \\
\hline
\end{tabular}

$$
\begin{aligned}
\text { Keterangan : } & \text { I = Konsep } \\
& \text { II = Keterampilan } \\
& \text { III = Pemecahan masalah }
\end{aligned}
$$

Berikut penyajian data hasil wawancara kepada 6 mahasiswa yang terdiri dari 2 kelompok atas, 2 kelompok sedang dan 2 kelompok bawah.

a. Kelompok Atas

\begin{tabular}{|c|c|c|}
\hline Subjek & $\begin{array}{c}\text { Nomor } \\
\text { Soal }\end{array}$ & Data Temuan \\
\hline Nadhiroh & 3 & $\begin{array}{c}\text { Mahasiswa belum memahami } \\
\text { konsep mengubah kalimat ke } \\
\text { dalam bentuk proposisi }\end{array}$ \\
mahasiswa tidak dapat me- \\
nentukan rumus yang digu- \\
nakan untuk menyelesaikan \\
soal distianah
\end{tabular}


b. Kelompok Sedang

\begin{tabular}{|c|c|c|}
\hline Subjek & Nomor Soal & Data Temuan \\
\hline \multirow{3}{*}{$\begin{array}{l}\text { Ahmad } \\
\text { Syafi'i }\end{array}$} & 1,4 & $\begin{array}{l}\text { mahasiswa tidak dapat menen- } \\
\text { tukan rumus yang digunakan } \\
\text { untuk menyelesaikan soal }\end{array}$ \\
\hline & 3 & $\begin{array}{l}\text { mahasiswa belum memahami } \\
\text { konsep mengubah kalimat ke } \\
\text { dalam bentuk proposisi }\end{array}$ \\
\hline & 5 & $\begin{array}{l}\text { mahasiswa tidak dapat meny- } \\
\text { elesaikan soal }\end{array}$ \\
\hline \multirow{3}{*}{ Tajkiyah } & 1 & $\begin{array}{l}\text { mahasiswa tidak dapat meny- } \\
\text { elesaikan soal }\end{array}$ \\
\hline & 3,5 & $\begin{array}{l}\text { mahasiswa tidak dapat menen- } \\
\text { tukan rumus yang digunakan } \\
\text { untuk menyelesaikan soal }\end{array}$ \\
\hline & 4 & $\begin{array}{l}\text { mahasiswa belum memahami } \\
\text { konsep mengubah kalimat ke } \\
\text { dalam bentuk proposisi }\end{array}$ \\
\hline
\end{tabular}


c. Kelompok Bawah

\begin{tabular}{|c|c|c|}
\hline Subjek & Nomor Soal & Data Temuan \\
\hline $\begin{array}{c}\text { Nur Zain } \\
\text { Nutfiyah }\end{array}$ & $1,2,5$ & $\begin{array}{c}\text { mahasiswa belum memahami } \\
\text { konsep mengubah kalimat ke } \\
\text { dalam bentuk proposisi }\end{array}$ \\
Ibnu Wahid & 3,4 & $\begin{array}{c}\text { mahasiswa tidak dapat me- } \\
\text { nentukan rumus yang digu- } \\
\text { nakan untuk menyelesaikan } \\
\text { soal }\end{array}$ \\
\hline & $1,3,4,5$ & $\begin{array}{c}\text { mahasiswa tidak dapat me- } \\
\text { nentukan rumus yang digu- } \\
\text { nakan untuk menyelesaikan } \\
\text { soal }\end{array}$ \\
\hline
\end{tabular}

Jika dilihat dari tabel di atas, semua mahasiswa yang menjadi subjek penelitian mengalami kesalahan pada pemahaman konsep yaitu sebesar 23,3\%. Selain itu ke-6 mahasiswa tersebut juga mengalami kesalahan dalam penguasaan keterampilan dalam mengerjakan soal-soal logika sebesar 40\%. Sedangkan untuk tingkat pemecahan masalah hanya 3 mahasiswa saja yang melakukan kesalahan dengan prosentase sebesar 10\%. Jadi, kesalahan yang tertinggi yang dilakukan oleh mahasiswa subjek penelitian adalah terletak pada keterampilan dalam mengerjakan soal-soal logika.

Selanjutnya, dari hasil wawancara diperoleh data bahwa pada prinsipnya mahasiswa memahami konsep-konsep dari logika, akan tetapi ketika mereka mengerjakan soal-soal logika tersebut banyak yang mengalami kebingungan dalam menentukan rumus atau dalil apa yang digunakan untuk menyelesaikan soal-soal tersebut, walaupun pada saat dosen menjelaskan ma- 
teri mereka sudah memahaminya. Karena hal itulah, kebanyakan mereka dalam mengerjakan soal cenderung memaksakan satu rumus atau dalil walaupun rumus tersebut tidak tepat, sehingga diperoleh hasil yang salah. Hal inilah yang menyebabkan tingginya prosentase kesalahan mahasiswa dalam penguasaan keterampilan pengerjaan soal-soal logika.

Dari hasil wawancara dengan subjek penelitian juga terungkap bahwa dari 6 responden 2 diantaranya adalah mahasiswa semester 7 yang mengulang pada mata kuliah PDM dikarenakan mendapat nilai jelek, sedangkan 4 mahasiswa yang lain adalah mahasiswa baru. Dari keempat mahasiswa baru ada 2 mahasiswa yang berasal dari MA jurusan IPS, mereka mengatakan di tingkat MA tidak mendapat materi logika yang diajarkan sehingga tidak dapat memahami konsep yang dijelaskan walaupun sudah mengikuti perkuliahan. Sedangkan kedua mahasiswa yang lain berasal dari SMA/MA jurusan IPA, tetapi mereka juga mengalami kesulitan karena materi yang disampaikan berbeda dengan yang diterima ketika di SMA/MA. Dan kedua mahasiswa yang mengulang, mereka mengakui bahwa sudah pernah mendapat materi tersebut dan memahami konsep-konsep dasar logika, hanya saja ada sebagian dari materi tersebut yang tidak dapat diingat karena sudah terlalu lama, sehingga ketika mengerjakan soal-soal logika masih bingung dalam menentukan rumus yang tepat untuk mencari langkah selanjutnya.

Terdapat satu kesamaan jawaban dari hasil wawancara dengan keenam mahasiswa subjek penelitian, yaitu bahwa mereka kurang banyak berlatih mengerjakan soal-soal yang terkait dengan logika. Walaupun mereka sudah menyadari bahwa tanpa banyak berlatih mengerjakan soal-soal logika, akan mustahil mereka dapat menguasai keterampilan dalam mengerjakan soal-soal tersebut.

Berikut beberapa faktor yang menyebabkan mahasiswa mengalami kesalahan dalam menyelesaikan soal-soal logika berdasarkan dari hasil wawancara yang telah dirangkum, yaitu: 1. Mahasiswa tidak menguasai dan memahami konsep-konsep sebelumnya yang digunakan dalam materi yang dipelajari 
dalam hal ini materi logika.

2. Abstraknya materi logika sehingga mahasiswa merasa malas dan bosan, yang menjadikan minat mahasiswa rendah dalam belajar matematika terutama materi logika.

3. Kurangnya latihan dalam mengerjakan soal-soal logika sehingga kesalahan mahasiswa terutama pada kemampuan penguasaan keterampilan dalam menyelesaikan soal cukup banyak.

Hasil yang diperoleh di atas, merupakan penjabaran dari data nilai yang diperoleh dan dipadukan dengan hasil wawancara terhadap subjek penelitian. Tidak menutup kemungkinan masih ada faktor lain yang menyebabkan mahasiswa melakukan kesalahan dalam menyelesaikan soal-soal logika, yang tidak terungkap baik dari hasil wawancara maupun dari hasil tes.

\section{PENUTUP}

Dari hasil pembahasan terhadap data-data yang diperoleh dari hasil penelitian, maka diambil simpulan, yaitu:

1. Letak kesalahan mahasiswa dalam menyelesaikan soal-soal logika yaitu pada bagian konsep, keterampilan dan pemecahan masalah. Kesalahan dalam konsep sebesar 7,5\%, kesalahan pada keterampilan sebesar 22,1\%, dan kesalahan pada pemecahan masalah sebesar $17,3 \%$. Jadi dapat disimpulkan kesalahan tertinggi mahasiswa dalam menyelesaikan soalsoal logika terletak pada keterampilan yaitu sebesar 22,1\%.

2. Faktor-faktor yang menyebabkan mahasiswa mengalami kesalahan dalam menyelesaikan soal-soal logika adalah:

a. Mahasiswa tidak menguasai konsep-konsep sebelumnya yang digunakan dalam materi yang dipelajari.

b. Abstraknya materi logika sehingga mahasiswa merasa malas dan bosan, yang menjadikan minat mahasiswa rendah dalam belajar matematika.

c. Kurangnya latihan dalam mengerjakan soal-soal logika sehingga kesalahan mahasiswa terutama pada keterampilan cukup banyak. 


\section{DAFTAR PUSTAKA}

Abdurrahman, Mulyono. 1999. Pendidikan Bagi Anak Berkesulitan Belajar. Jakarta: Rineka Cipta.

Al-Maraghi, Ahmad Musthofa. 1993. Terjemah Tafsir Al-Maraghi 13. Semarang : PT. Karya Toha Putra Semarang. hlm. 29

Suyitno, Amin. 2004. Dasar-dasar dan Proses Pembelajaran Matematika I. Semarang: Unnes.

Windarti, Sri. "Dunia Matematika", dalam http://sriwindarti. wordpress.com/2009/03/17/mengembangkan-evaluasialternatif/, diakses 3 Mei 2011.

Yunus , Muhammad. 1994. Terjemah al-Qur'an al-Karim. Bandung:PT al-Ma'arif, hlm. 244. 
Analisis Kesalahan Mahasiswa Matematika ......

Jurnal PHENOMENON, Volume 2 Nomor 1, Juli 201293 